\title{
Tervetullut oppikirja monikulttuurisesta hoitotyöstä
}

Pirkko Abdelhamid, Anitta Juntunen \& Liisa Koskinen (2009).

Monikulttuurinen hoitotyö. WSOYpro Oy.

UUSI OPPIKIRJA voi muuttaa opetusta enemmän kuin opetussuunnitelmien uudistaminen. Monikulttuurisen hoitotyön oppikirjalla voi olla rikastava muutosvaikutus hoito- ja sosiaalialan opetukseen ja ammatilliseen arkeen. Hoitotyön arkihan on monikulttuurista. Samoin globaali liikkuvuus on hoitotyön ammattikunnalle ominaista.

Voikin hämmästellä, miksi monikulttuurisuutta on käsitelty aiemmin varsin sattumanvaraisesti suomenkielisissä hoitoalan oppikirjoissa. Ehkä siksi, että monikulttuurisuuden käsittely vaatii tietoa, taitoa ja rohkeutta jäsentää laajan ilmiön merkitystä hoitotyössä.

Pirkko Abdelhamid, Anitta Juntunen ja Liisa Koskinen monikulttuurisen hoito- ja opetusalan pioneerityön tuloksena on saatu opetuksen tueksi laaja-alainen monikulttuurisen hoitotyön julkaisu. Kirjoittajat ovat sekä ammattikasvatuksen asiantuntijoita että monikulttuurisen terveydenhuollon tutkijoita ja opettajia, joista Abdelhamid ja Koskinen toimi- vat Savonian ja Juntunen Kajaanin ammattikorkeakouluissa.

Teos palvelee erityisesti ammatti- ja korkeakoulujen hoito- ja sosiaalialan opettajia, aikuiskasvattajia, opiskelijoita sekä hoito- ja sosiaalialan ammattilaisia. Kirja on tosin mielenkiintoista luettavaa kenelle tahansa monikulttuurisista kysymyksistä kiinnostuneille. Terveys on globaali ilmiö, joka saa kuitenkin hyvinkin kulttuurisidonnaisia tulkintoja, kun siirrymme selittämään sairauksia, niiden syntyä, hoitokeinoja ja taitoa kohdata hoitoa tarvitseva ihminen, kuten kirjoittajat osoittavat.

\section{PUNAINEN LANKA}

Kirjan juoni seuraa Josepha Campinha-Bacoten kulttuurisen osaamisen prosessimallia. Tämän mukaan monikulttuurisen hoitotyön oppimisprosessi jäsentyy kuuteen lukuun, joissa avautuvat seuraavat keskeiset käsitteet: kulttuurinen tahto, kulttuurinen tietoisuus, kulttuurinen tieto, kulttuurinen taito ja kulttuuriset kohtaamiset. Seitsemännessä luvussa kirjoitta- jat avaavat monikulttuurisen terveydenedistämisen haasteita.

Kunkin luvun pedagogiset tavoitteet on jäsennetty osaamisperustaisesti, mikä auttaa lukijaa arvioimaan omaa oppimistaan. Luvun tavoitteiden mukaisesti lukija voi kysyä itseltään esimerkiksi, ymmärsinkö tahdon merkityksen kulttuurisen osaamisen käynnistävänä voimana; tai ymmärsinkö transnationaalisen osaamisen mallin perusidean; kiinnostuinko oman kulttuurisen osaamisen arvioinnista; tunnistanko eettisten ongelmien luonteen monikulttuurisessa hoitotyössä; osaanko selittää kulttuuristen taustatietojen ja uskomusten merkityksen hoitotyössä; osaanko soveltaa kulttuurista tietoa hoitotyössä ja terveyden edistämisessä; osaanko rakentaa monikulttuurisen hoitosuhteen; pystynkö arvioimaan monikulttuurisista lähtökohdista potilaan hoitotyön prosessia.

Kirjan osaamisperustainen jäsennys palvelee myös korkeakoulujen opetuksen suunnittelua ja toteutusta, joka tulee perustu- 


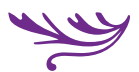

maan osaamisperustaisiin opetussuunnitelmiin vuoteen 2012 mennessä.

\section{KULTTUURINEN TAHTO}

Campinha-Bacoten tulivuorimalli lähtee purkautumaan siitä, että ammattilaisissa herää kulttuurinen tahto kehittää kulttuurista osaamista hoitotyössä. Kun hoitajat ymmärtävät kulttuurin merkityksen ihmisen terveydelle, heissä syntyy myös tahto oppia vastaamaan havaittuihin tarpeisiin. Asiakaskeskeisyys korostuu nykypäivän hoitopolitiikassa ja käytännöissä, mikä edistänee kulttuurisen tahtotilan syntymistä.

Kirjassa ei korvata kulttuurisidonnaisilla uskomuksilla ihmisen sairauksien luonnontieteellisiä selityksiä. Sen sijaan lukijalle tarjotaan mahdollisuus ymmärtää ihmisen terveys- ja sairauskokemusta laajemmin kuin fysiologisesti ja biokemiallisten prosessien kautta. Ihmisen epäkuntoon mennyt koneisto ei korjaudu yksinomaan mekaanisin hoitotoimenpitein ja lääkehoidolla, vaan vaatii myös ymmärrystä siitä, miten ihminen itse selittää terveyttään ja sairastumistaan sekä sen hoitoa. Tähän kirja tarjoaa runsaasti näkökulmia.

\section{TIETOISUUS, TIETO JA TAITO}

Kulttuurisen tietoisuuden prosessi haastaa hoitajan tunnistamaan ja tutkimaan ammattieettisten periaatteiden kulttuurista perustaa. Vastaaminen eri kulttuureista tulevien potilaiden ja asiakkaiden tarpeisiin edellyttää hoitajalta perinteisen potilashoidon näkökulman laajentamista. Hoitotoimenpiteiden lisäksi myös hoitoon hakeutuminen ja hoidon tarjoaminen kiinnittyvät kulttuuriin.

"Kyetäkseen toimimaan potilaan parhaaksi hoitajan on ymmärrettävä, miten kulttuuri, etninen tausta, uskonto, sukupuoli, koulutustausta, sosiaalinen asema, elämäntapa ja ikä vaikuttavat ihmisen inhimilliseen käyttäytymiseen, terveydentilaan ja terveysuskomuksiin sekä kykyyn ja mahdollisuuksiin hakea ja saada hoitoa", avaa Pirkko Abdelhamid hoitotyön eettisten periaatteiden kulttuurista luonnetta ja huolenpidon etiikkaa, mikä kehystää hoitotyötä ja luo "näyttämön" hoitohenkilökunnan ja asiakkaiden kohtaamisille (s.77).

Hoitotyössä tarvittavan asiakastiedon keräämiseen kirjan tekijät tarjoavat kulttuurienvälisessä tutkimuksessa tuotettuja teoreettisia malleja ja välineitä.

"Rohkea ja myötäelävä hoitaja, joka on halukas kehittämään monikulttuurisen hoitotyön taitojaan, onnistuu kulttuuristen tarpeiden arvioinnissa, vaikka siihen ei suomalaisessa hoito- kulttuurissa ole totuttu (s. 138)," uskovat kirjoittajat.

\section{KULTTUURISENSITIIVISET KOHTAAMISET}

Kulttuurisensitiivinen potilaan kohtaaminen merkitsee muiden muassa kulttuuristen oireyhtymien tunnistamista, kivun tulkintaa ja lääkehoitoa, kuolevan potilaan kohtaamista sekä toisesta kulttuurista tulevien ihmisten terveyden edistämistä heidän elämäkulkunsa eri vaiheissa (s. 157-257). Kohtaamisia avataan kirjassa tapauskohtaisten kuvausten kautta.

Ammattialan henkilöstön kokemukset voivat osaltaan ohjata hyvien hoitokäytänteiden luomista. Tähän kirja tarjoaa monipuolisia virikkeitä. Kuitenkin käytännön hoitotoimenpiteissä Suomessa korostuu, monien muiden Euroopan maiden tavoin, tutkimusnäyttöön perustuvat hyvät hoitokäytännöt. Kärjistäen tämä tarkoittaa sitä, että mikäli terveydenhoidossa ei ole tarjolla hoitoa määrittävää tutkimusnäyttöä, tietoa ei ole.

Kansainvälinen tutkimus on tuottanut tietoa maahanmuuttajien terveydestä ja terveyseroista eri maissa, mutta se on pirstaleista. Muiden muassa EU:n Costtutkijaverkosto Health and Social Care for Migrants and Ethnic Minorities in Europe (HOME) pyrki 


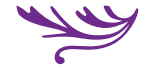

kokoamaan näyttöä hyvistä monikulttuurista hoitokäytänteistä, terveyspolitiikasta ja etnisten ryhmien terveyseroista 28 maan yhteistyönä. Suomessa on puolestaan toteutusvaiheessa laaja maahanmuuttajaväestön terveydentilaa, hyvinvointia ja palvelukokemuksia kartoittava tutkimus (www.thl. fi/maamu ). Maamussa tutkitaan THL:n johdolla 3000 venäläis-, somali- ja kurditaustaisen aikuisen terveyttä ja hyvinvointia kuudessa kaupungissa 2010-2012. Tutkimustieto ja käytännön kokemus toimivista ratkaisuista edistävät näyttöön perustuvien hoitokäytänteiden luomista maahanmuuttajaväestön tarpeita vastaavasti.

\section{STRATEGINEN TUKI}

Yhdenvertaisen ja monikulttuurisen terveydenhoidon toteuttamisen edellytyksenä ovat terveysalan johdon strateginen tuki ja hyvien monikulttuuristen hoitokäytänteiden linjaukset. Miten johto tukee monikulttuurisen hoitotyön toteutumista Suomessa osana eurooppalaista terveydenhoitopolitiikkaa, jossa niin asiakkaat kuin terveydenhoitohenkilökunta liikkuvat kasvavassa määrin? Tähän kysymykseen monikulttuurinen hoitotyön kirja ei pyrikään vastaamaan. Se pitäytyy asiakaslähtöisessä hoidossa.
Myös terveydenhoitoyhteisöt ovat moninaistuneet Suomessa hyvin nopeasti erityisesti pääkaupunkiseudulla. Tämä avaa pohdittavaksi myös monimuotoisuuden johtamisen käytänteet, kuten eri kulttuureista tulevien ammattilaisten henkilöstösuunnitteluun ja -hankintaan, työhön opastukseen ja urakehitykseen, tulkkauskysymyksiin, motivointiin sekä viestintään liittyvät toimintatavat. Monikulttuurinen terveydenhuolto edellyttää yhdenvertaisuuden toteuttamista sekä asiakaspinnassa että henkilöstöpolitiikassa (Yhdenvertaisuuslaki 20.1.2004/21).

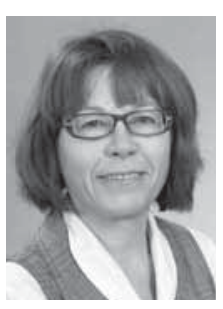

Kaija Matinheikki-Kokko

PsT, yliopettaja,

Metropolia-ammattikorkeakoulu

Monikulttuurisen opetuksen ja

ohjauksen dosentti,

Jyväskylän yliopisto

\section{LÄHTEITÄ}

COST Action IS0603 (2007-2011). Health and Social Care for Migrants and Ethnic Minorities in Europe (HOME). http://www.costhome.eu/ management/index.php/Main_Page 